\title{
Using Peer-Modo Feedback at the Pre-Writing Stage to Improve Year 4 Pupils' Writing Performance
}

\author{
Aderlin Chung Kim Yuk ${ }^{1 \rtimes}$ \\ Melor Md Yunus ${ }^{(D)}$
}

'English Teacher at English Department of a Primary School, Johor, Malaysia.

Email:yuky92@gmail.com Tel: 60198193872

'Associate Professor of TESL at Faculty of Education, University Kebangsaan Malaysia, Bangi, Selangor,

Malaysia.

Email:melor@ukm.edu.myTel:60192644401

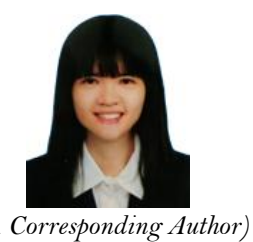

\begin{abstract}
The main problem faced by English teachers in the current English as a Second Language (ESL) writing classroom was a lack of strategies to support the process of teaching and learning writing that would help to enhance the content quality of pupils' writing performance. Additionally, primary pupils were found to face difficulties with getting started in writing. Peer feedback is an important tool for encouraging and consolidating learning. A quasi-experimental research study was implemented to investigate the effectiveness of an online peer-feedback strategy using Edmodo at the pre-writing stage to improve pupils' writing performance. A writing pre-test and post-test were administered to 36 Primary 4 respondents from a Chinese-vernacular school in a state in southern Malaysia to reveal their writing test scores before and after the intervention. Documents such as pre-test and post-test writing excerpts and Peer-Modo feedback comments were analyzed to corroborate the quantitative findings of the test scores. The results of the mean scores of the pre-test and post-test showed that there was significant improvement in pupils' writing ability. The document analysis reflected significant improvements in terms of the content quality of their writing after conducting Peer-Modo feedback. Consequently, online peer feedback strategies should be taken into consideration in the teaching of writing in the ESL classroom.
\end{abstract}

Keywords: Peer feedback, Pre-writing stage, ESL writing classroom, Primary education, Social learning platform, Content quality, Writing performance.

Citation | Aderlin Chung Kim Yuk; Melor Md Yunus (2021). Using Peer-Modo Feedback at the Pre-Writing Stage to Improve Year 4 Pupils' Writing Performance. Journal of Education and eLearning Research, 8(1): 116-124.

History:

Received: 29 December 2020

Revised: 18 January 2021

Revised: 18 January 2021

Published: 15 February 2021

Licensed: This work is licensed under a Creative Commons Attribution 3.0 License (c)

Publisher: Asian Online Journal Publishing Group
Acknowledgement: Both authors contributed to the conception and design of the study.

Funding: This research was supported by the grant from the Faculty of Education, Universiti Kebangsaan Malaysia GG-2018-001 and GG-2019-009. Competing Interests: The authors declare that they have no conflict of interests.

Transparency: The authors confirm that the manuscript is an honest, accurate, and transparent account of the study was reported; that no vital accurate, and transparent account of the study was reported; that no vital
features of the study have been omitted; and that any discrepancies from the study as planned have been explained.

Ethical: This study follows all ethical practices during writing.

\section{Contents}

1. Introduction

3. Methodology

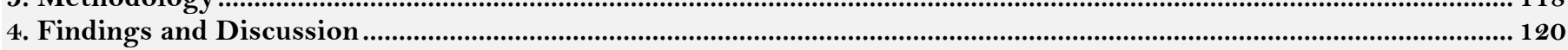

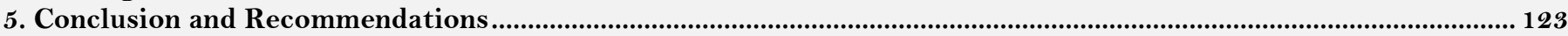

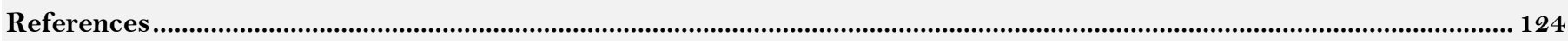




\section{Contribution of this paper to the literature}

This paper provides an insight to readers in the effectiveness of carrying out Peer-Modo feedback at the pre-writing stage in the teaching and learning of writing. Readers will be shown that the strategy can be used to increase the content quality of students' writing products.

\section{Introduction}

Learning writing skills is just as important as learning to speak, listen, and read. According to Mogahed (2013), writing is considered to be one of the basic skills for literacy. In order to disseminate ideas effectively and efficiently, students should build an early foundation in writing. The written text of an effective English as a Second Language (ESL) writer must be cohesive, logical, clearly structured, interesting, and properly organized, with a wide range of vocabulary and a mastery of the conventions of mechanics (Fareed, Ashraf, \& Bilal, 2016). Writing skills are essential to the learning process of ESL learners, as they represent a comprehensive skill that helps to strengthen vocabulary, grammar, thinking, planning, editing, revising, and other elements (Lim, Yunus, \& Embi, 2017). Students' ability to present information and express their own ideas through writing also plays a very significant role in their future success, both in the academic and the professional sphere.

In the Malaysian education system, English is taught and learned as a second language. The English language curriculum aims to prepare pupils with fundamental language skills in order for them to focus on critical literacy development. As one of the basic skills for literacy, in order to disseminate ideas effectively and efficiently, students should build an early foundation in writing. In the primary school curriculum, learners' writing ability is developed from the word and phrase level, extending to the sentence and paragraph level. By the end of their primary education, pupils should be able to write a variety of texts using appropriate language, style, and form, using a variety of media (Ministry of Education Malaysia, 2015).

In the context of the present study, the teaching and learning process in writing classes did not seem to enable pupils to become successful writers, especially in terms of the content quality of their writing. They were facing the problem that they lacked their own ideas to support the main arguments of their writing, which caused poor writing performance among the pupils. Two potential causes for this problem were identified. First, the strategies employed in the process of teaching and learning to write were insufficient. Similar to Kuyyogsuy's (2019) assertion, there is a lack of effort on the teacher's part in writing instruction with regards to commenting, suggesting, and providing good quality feedback to increase learners' writing competence. The second reason is neglect of the pre-writing stage, which is the most crucial stage in the writing process. Pupils were struggling to get started on their essay and to write details that supported their main ideas. However, the primary learners were unaware of how a pre-writing strategy could improve their writing experience (Yunus et al., 2018). Abdullah, Hashim, and Mahmud (2018) also reported that the pre-writing stage was frequently overlooked by beginner writers and was also the most strenuous part of writing. It is necessary to spend considerable time and attention on the pre-writing stage, as it helps to solve 'writer's block' (Mogahed, 2013).

Teachers ought therefore to provide a variety of learning experiences and resources at the pre-writing stage so that pupils will struggle less with the completion of writing tasks. In this study, Peer-Modo feedback (peer feedback with the incorporation of the social learning platform Edmodo) was employed as a teaching strategy to develop primary pupils' writing skills at the pre-writing stage and increase their writing performance at the drafting stage. Edmodo was chosen as the learning platform because it utilizes a similar layout and functions to popular social media platforms such as Facebook and Twitter. The resemblance to Facebook, a prevailing social media platform among students, would ensure that pupils would be comfortable using Edmodo.

In this study, content quality, content organization, and accuracy were the three writing features which were equally given attention to in the feedback giving exercise and the evaluation of the respondents' writing. The current paper, however, only discusses the content quality out of the three writing features. The research questions were formulated as below:

1. Is there any significant difference in the mean score for writing performance between the experimental and control groups before and after Peer-Modo feedback?

2. Is there any significant improvement in terms of the content quality of the written product?

\section{Literature Review}

\subsection{Online Peer Feedback at Pre-Writing Stage}

Pre-writing is the first stage of the writing process, followed by drafting, revision, editing, and publishing. In the pre-writing stage, students are encouraged to write an outline of the given topic by generating ideas through brainstorming, clustering, rapid free writing, and WH-questions. Many young writers find that it is difficult to start writing. Tompkins (2001) noted that the most neglected stage of writing is the pre-writing stage. Research has shown that learners who are encouraged to engage in an array of pre-writing activities prove greater writing achievement than those who were instructed to write without this kind of preparation (Cotton 1997 as cited by Mogahed (2013). Therefore, pre-writing centres on engaging learners in the writing process. To English teachers, pre-writing should not be viewed as an isolated stage but as an integral part of the whole process of pre-writing, drafting, revising, and editing (Go, 1994).

The use of technology in writing instruction accommodates learners with different learning styles, abilities, and interests. Technology also helps learners to practice different writing skills. In fact, the use of technology in teaching writing at the pre-writing stage is supported by past research findings. In the first place, learners are able to create, analyse, produce, and gain ideas more efficiently. Huang (1999) carried out a study to investigate the extent to which English as a Foreign Language (EFL) writing students at a Taiwanese university used ideas provided by their peers during computer-mediated pre-writing discussions, and the quality of peers' comments. The results indicated that students did use some ideas discussed during the computer-mediated pre-writing discussions. The activities that students perceived as useful in idea generation were the students' own ideas, ideas from friends, textual information from textbooks and teacher handouts, and computer-mediated pre-writing discussions. 
Sharadgah (2013) investigated the effect of an Internet based instructional program (IBIP) on developing the writing performance of students in tertiary education. The program offered the learners an environment for collaborative and peer review practices at the pre-writing stage. The findings revealed that students shared and exchanged ideas and thoughts about the writing topic using the text-based chat. Peer review also offers the opportunity for students to benefit from other students' information and knowledge. In the linguistic field, peer feedback activities have been shown to encourage pupils to engage in teacher-student interactions and peer interactions by using a variety of language functions such as asking questions, offering explanations, giving suggestions, restating what their peers have said or written, and correcting grammar mistakes (Mendonca \& Johnson, 1994).

As opposed to the traditional method, in which students often write for the teacher alone, writing outlines on Edmodo means writing for a wider audience, since it is shared with both teachers as well as the other pupils who are in the group (Lo \& Hyland, 2007). There are other pupils or other teachers who will read and give feedback on what has been written. Peer feedback activities by means of online social networks have the potential to generate more comments on the content and organization the writing (Kuyyogsuy, 2019). This is also supported by Mohamad, Ghazali, and Hashim (2018) who report that peer feedback through online learning platforms provides students with convenient and attractive features to engage them in knowledge sharing, allowing them to give feedback and add new ideas to others' writing and review their own writing at their own pace.

\subsection{Effects of Peer Feedback on Writing Performance}

Many studies on peer feedback have been carried out over the years to study the effects of peer feedback on students' writing performance. By providing peer feedback training to learners, they are able to give more constructive feedback to their peers while the receivers are able to use the feedback they received to make improvements to their essays (Yang \& Meng, 2013). Constructive feedback includes commentary on positive and negative aspects. The peer editor does not rectify the errors in peers' writing, but they review the mistakes by pointing them out and making them clearer to writers (Tusino, 2013). In this study, the peer feedback strategy is implemented at the pre-writing stage as (McKee 1981 as cited by Geyimci (2014) posits that without pre-writing guidance, pupils might have trouble expressing their ideas due to limitations of their language. He also states that pre-writing techniques help students to get ideas before proceeding to the drafting stage. Peer feedback exposes students to new perspectives on the writing process and provides them with more practice in the development of their language and writing abilities (Yusof, Ab Manan, \& Alias, 2012).

Peer feedback sessions allow students to explain the corrections to each other's writing and give feedback on different aspects of the writing, for example the content quality (Parthasarathy, 2014). Some studies have been carried out that show the consequences of peer feedback on the content quality of an essay (Calimbo, Arambala, Sususco, \& Talle, 2016; Latifi, Noroozi, Hatami, \& Biemans, 2019; Moussaoui, 2012; Said et al., 2013). An essay with high content quality is made up of main ideas relevant to the provided topic with supporting details for each main idea to strengthen why something should or should not be the case (Atikah, 2013). Collaborative editing methods help learners to write a unified composition with a clear focus and sufficient support of the topic sentence (content aspect) (Calimbo et al., 2016). The study also found that the average scores of participants differed according to the evaluation method employed (namely self-evaluation, one-on-one evaluation, and peer group evaluation). Peer group evaluation appeared to have a stronger impact on the content of participants' essays compared to the other methods. In addition, a survey study carried out by Said et al. (2013) reported that writing for a larger audience could enhance the quality of academic writing, as the participants paid more attention to the content and language use in their writing. Thus, this study brings forward the peer-feedback intervention as a preliminary to the drafting stage so that the primary learners are aware and ready to write a piece of work with a high content quality. The current study intends to discover whether peer-feedback at the pre-writing stage has a positive impact on the content quality of respondents' written product.

In the current study, the users of the peer feedback strategy played two major roles, as feedback reviewers and feedback receivers. According to Lundstrom and Baker (2009) reviewers showed greater refinement in their own writing than feedback receivers who relied on peer feedback to enhance their writing. This is made evident through the experimental study of Yusof et al. (2012) who discovered that reviewers achieved an overall improvement of their writing score compared to receivers. Although their own writing outlines were not reviewed, engagement in the feedback giving exercise can hone the pre-writing skills and self-editing skills of reviewers. The current study also aims to uncover whether Peer-Modo feedback can improve the writing performance of both feedback reviewers and feedback receivers.

\section{Methodology}

\subsection{Research Design and Research Respondents}

This was a quasi-experimental research study which employed a non-equivalent control group pre-test-posttest design in order to explore the effects of using Peer-Modo feedback at the pre-writing stage on pupils' writing performance. A total of 36 Primary 4 respondents were selected from an urban Chinese-vernacular school in the southern state of Malaysia. All respondents were social media users, and they were introduced to Edmodo at the beginning of the research. Their English proficiency was at intermediate level. In this study, the experimental group and the control group of pupils were chosen without random assignment. The experimental group acted as both feedback reviewer and receiver while the control group acted only as feedback reviewer. The rationale of having a control group whose pre-writing outlines were not reviewed was to get the respondents to focus more closely on just a few pre-writing outlines and therefore be more critical in giving feedback. This would also help to reveal whether the control group would perform better by just giving feedback to others, without having their own pre-writing outline reviewed.

Prior to the Peer-Modo feedback intervention, at the first session, the pupils (in pairs) outlined the main ideas 
and supporting details of their essay topic: the choice of a birthday gift for their father. The draft they produced was considered the pre-test and their test scores were recorded as pre-test scores. The written outlines of the pupils in the experimental group were posted on Edmodo for all respondents to review. Subsequently, the respondents from the experimental group wrote their first draft based on the feedback received while the respondents from the control group wrote without having had their pre-writing products reviewed. The drafts were assessed and the test scores were recorded as post-test scores.

Pre-test and post-test scores were used to investigate whether there was any statistically significant difference between the pre-test and post-test results for both experimental and control groups after the Peer-Modo feedback intervention. Their writing outlines were evaluated quantitatively by using a Peer-Modo rubric for pre-test and post-test evaluation, see Figure 1. The marks were recorded by the teacher as pre-test score and post-test score. The evaluation criteria included aspects of content (relevancy and richness of ideas, with main ideas and supporting details), format and organization of the essay (whether all ideas were organized into three paragraphs following the format of ICC (Introduction, Content and Conclusion) and whether the word count was within 50-80 words) and finally mechanics and grammar. Mechanics encompassed spelling, capitalization, handwriting, and meaning of the sentence. Grammar concerned the use of language in creating simple, compound, or complex sentences; tense, word order, pronouns, articles, etc.; and correct use and command of vocabulary.

\section{Peer-Modo Rubrics}

\begin{tabular}{|c|c|c|c|c|c|}
\hline \multicolumn{6}{|c|}{ Total score (12 marks) } \\
\hline Band & Super excellent & Excellent & Good & Satisfactory & Weak \\
\hline $\begin{array}{c}\text { Score for each } \\
\text { criterion }\end{array}$ & 4 & 3 & 2 & $\mathbf{l}$ & 0 \\
\hline Content & $\begin{array}{l}\text { - All ideas are } \\
\text { very relevant. } \\
\text { - All the main } \\
\text { ideas are } \\
\text { written with } \\
\text { supporting } \\
\text { details. }\end{array}$ & $\begin{array}{l}\text { - } 2 \text { out of } 3 \text { of } \\
\text { the ideas are } \\
\text { relevant. } \\
\text { - } 2 \text { out of } 3 \\
\text { main ideas are } \\
\text { written with } \\
\text { supporting } \\
\text { details. }\end{array}$ & $\begin{array}{l}\text { - } \begin{array}{l}1 \text { out of } 3 \\
\text { ideas are } \\
\text { relevant. }\end{array} \\
\text { - } 1 \text { out of } 3 \text { main } \\
\text { ideas are } \\
\text { written with } \\
\text { supporting } \\
\text { details. }\end{array}$ & $\begin{array}{l}\text { Main ideas } \\
\text { are written } \\
\text { without any } \\
\text { supporting } \\
\text { details. }\end{array}$ & $\begin{array}{l}\text { - All the ideas } \\
\text { are in chunks. }\end{array}$ \\
\hline $\begin{array}{c}\text { Organization } \\
\text { and format }\end{array}$ & $\begin{array}{l}\text { - All ideas are } \\
\text { well } \\
\text { organised in } 3 \\
\text { paragraphs. } \\
\text { - The format of } \\
\text { writing is } \\
\text { correct } \\
\text { without any } \\
\text { errors. }\end{array}$ & $\begin{array}{l}\text { - All ideas are } \\
\text { well } \\
\text { organised in } 3 \\
\text { paragraphs. } \\
\text { - The format of } \\
\text { writing } \\
\text { contains } 1 \\
\text { error. }\end{array}$ & $\begin{array}{l}\text { - All ideas are } \\
\text { organised in } \\
\text { only } 2 \\
\text { paragraphs. } \\
\text { - The format of } \\
\text { writing } \\
\text { contains } 2 \\
\text { errors. }\end{array}$ & $\begin{array}{l}\text { - All ideas are } \\
\text { organised in } \\
\text { only } 1 \\
\text { paragraph. } \\
\text { - The format of } \\
\text { writing } \\
\text { contains } 3 \\
\text { errors. }\end{array}$ & $\begin{array}{l}\text { - All ideas are } \\
\text { organised in } \\
\text { only } 1 \\
\text { paragraph. } \\
\text { - The format of } \\
\text { writing is } \\
\text { totally } \\
\text { incorrect. }\end{array}$ \\
\hline $\begin{array}{c}\text { Mechanics \& } \\
\text { Grammar }\end{array}$ & $\begin{array}{l}\text { - Almost } \\
\text { perfect in } \\
\text { punctuation } \\
\text { and spelling } \\
\text { with high } \\
\text { command of } \\
\text { vocabulary. } \\
\text { - Less than } 3 \\
\text { errors in } \\
\text { grammar and } \\
\text { structures. }\end{array}$ & $\begin{array}{l}\text { - A few errors } \\
\text { in } \\
\text { punctuation } \\
\text { and spelling } \\
\text { and correct } \\
\text { use of } \\
\text { vocabulary. } \\
\\
\text { - Less than } 5 \\
\text { errors in } \\
\text { grammar and } \\
\text { structures. }\end{array}$ & $\begin{array}{l}\text { - Some errors } \\
\text { in } \\
\text { punctuation } \\
\text { and spelling. } \\
\text { Vocabulary is } \\
\text { just } \\
\text { sufficient. } \\
\text { - Some errors } \\
\text { in both } \\
\text { grammar and } \\
\text { postures. }\end{array}$ & 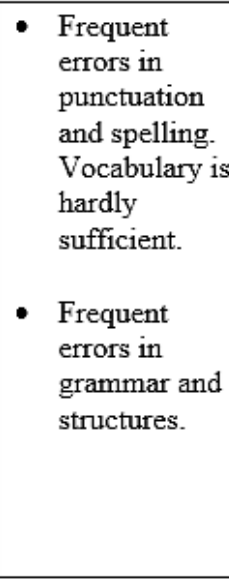 & $\begin{array}{l}\text { - Spelling and } \\
\text { punctuation } \\
\text { errors are } \\
\text { found } \\
\text { throughout } \\
\text { the essay. } \\
\text { Vocabulary } \\
\text { hardly } \\
\text { conveys } \\
\text { meaning. } \\
\text { - Many } \\
\text { multiple } \\
\text { errors in } \\
\text { grammar and } \\
\text { structures. }\end{array}$ \\
\hline
\end{tabular}

Figure-1. Peer-Modo rubric used for pre-test and post-test evaluation.

In addition, documents such as participants' feedback on others' writing outlines on Edmodo and samples of pupils' pre-test and post-test writing were collected. These documents could be used to explore the content quality of pre-test and post-test paper writing to corroborate the quantitative findings collected in order to minimize the impact of bias from the test scores.

\subsection{Research Procedures}

There were three main instructional activities involved in the intervention, which were: free writing at the prewriting stage, Peer-Modo feedback training, and Peer-Modo feedback practice. During the Peer-Modo feedback intervention, both the experimental group and the control group went through five writing processes, namely prewriting --- (Peer-Modo feedback) $\rightarrow$ first draft $\rightarrow$ reviewing $\rightarrow$ revisiting $\rightarrow$ final draft. The introduction of the Peer-Modo feedback strategy to all respondents was adapted from Chamot (1999) and Grenfell and Harris (1999):

1. Awareness raising. Respondents were given a writing topic about choosing a food to eat during recess. After

the teacher explained the question requirement and the given information, respondents, in pairs, used the free

writing technique to outline their thoughts. They were told that what they were doing at this level was called the pre-writing stage.

2. Modelling. The teacher posted a few samples of outlines (pre-writing products) from the experimental group 
and posted them on Edmodo. Then, the teacher elicited feedback about the content quality, format and organization, and accuracy of each pre-writing product based on the task given (i.e., the type of feedback that the researcher wished to collect from the respondents), as shown in Figure 2. The feedback elicited from the respondents was written in the comments section under the post of each outline in Edmodo so that all respondents could see each other's comments.

Ms. Aderlin posted to 6 Melbourne
Teacher at SJKC FOON YEW 1
Sep 25 $2: 32$ AM

Figure-2. A sample of the tasks for Peer-Modo feedback.

Source: Based on author's preferred methodology.

3. General practice: In pairs, respondents practised giving feedback on peers' outlines. The teacher constantly monitored their responses and prompted them accordingly to assist them to give constructive comments. The teacher also highlighted the constructive feedback by using the 'Like' feature.

4. Evaluation: Respondents referred to their own pre-writing products. By using the knowledge that they had gained from the Peer-Modo strategy, respondents produced their first draft. Then, they were asked to review their own writing by following the rubric and make any amendments to their draft.

5. Expansion and Assessment: Respondents transferred the Peer-Modo feedback strategy to the test topic (choosing a birthday gift for father). In pairs, they outlined the main ideas and supporting details of their essay. The outlines of the respondents from the experimental group were posted on Edmodo for all respondents to review. After that, respondents from the experimental group wrote their first draft based on the feedback received while the respondents from control group wrote without having had their pre-writing products reviewed.

\subsection{Data Analysis}

Results were collected, processed, and analysed descriptively using frequency counts and percentage distribution. The analysed descriptive data was presented in table form. Then, paired-sample t-tests (for normal data distribution) and Wilcoxon matched-pairs signed rank tests (for not normal data distribution) were used to discover whether there was any significant difference between the mean scores for writing performance before and after the intervention for the control group and for the experimental group. Content quality was one of the criteria used to assess pupils' writing performance. The same inferential statistics were also used to compare the pre-test and post-test scores on each writing feature in order to find out the difference in their writing performance with regards to content quality. Next, selected pre-writing outlines from the experimental group were analysed, with Peer-Modo feedback given to show respondents' engagement in giving feedback on the basis of the content quality of their writing products. The pre-test and post-test writing products were compared in terms of content quality to consolidate the quantitative findings and minimize the impact of bias of data from the test scores.

\section{Findings and Discussion}

4.1. Is there any significant difference in writing performance mean scores for experimental and control groups before and after Peer-Modo feedback?

Based on Table 1, the mean pre-test score of both groups revealed that most of the respondents had the potential to write a good essay, even before the interventions were carried out. Most of them obtained a score of above 6.0 in their pre-test. After the Peer-Modo feedback intervention was carried out, an improvement in the post-test score was observed in both groups. Out of the 18 pairs of respondents, only four pairs had no improvement in the draft stage. In addition, it could be observed that the post-test score of the $9^{\text {th }}$ pair of respondents from the control group remarkably improved from a score of 2.0 to 10.0. This signifies the importance of peer feedback in helping pupils by exposing them to ideas which could help them to produce a better writing outline. The improvement could be also caused by the fact that the use of Edmodo stimulated pupils to engage themselves in learning writing from their peers.

The pre-test and post-test writing scores achieved by the experimental and control groups were further analysed and compared using a t-test. Before carrying out the t-test, a Shapiro-Wilk test was conducted to find out whether the pre-test and post-test writing score data for the respective experimental and control groups was normally distributed. The Shapiro-Wilk test showed a normal data distribution for the control group $(p=.228$, $>.05$ ), whereas the data distribution for the experimental group was not normally distributed $(\mathrm{p}=.003,<.05)$. Therefore, the mean scores for writing performance before and after the intervention for control group $\mathrm{p}$ were compared by using a paired sample t-test, see Table 2 , while the latter were compared using a Wilcoxon matchedpairs signed rank test, see Table 3. 


\begin{tabular}{|c|c|c|c|c|c|c|c|}
\hline \multirow{2}{*}{$\begin{array}{l}\text { Respondents } \\
\text { (in pair) }\end{array}$} & \multicolumn{3}{|c|}{ Experimental group } & \multirow{2}{*}{$\begin{array}{l}\text { Respondents } \\
\text { (in pair) }\end{array}$} & \multicolumn{3}{|c|}{ Control group } \\
\hline & $\begin{array}{c}\text { Pre-test } \\
(/ 12) \\
\end{array}$ & $\begin{array}{c}\text { Post- } \\
\text { test }\end{array}$ & $\begin{array}{c}\text { Score } \\
\text { difference }\end{array}$ & & $\begin{array}{l}\text { Pre- } \\
\text { test }\end{array}$ & $\begin{array}{c}\text { Post- } \\
\text { test }\end{array}$ & $\begin{array}{c}\text { Score } \\
\text { difference }\end{array}$ \\
\hline 1 & 7.0 & 9.5 & +2.5 & 1 & 9.0 & 9.0 & 0.0 \\
\hline 2 & 6.0 & 10.0 & +4.0 & 2 & 8.5 & 9.5 & +1.0 \\
\hline 3 & 6.5 & 9.0 & +2.5 & 3 & 7.5 & 8.5 & +1.0 \\
\hline 4 & 7.5 & 9.0 & +1.5 & 4 & 8.5 & 11.0 & +2.5 \\
\hline 5 & 7.0 & 11.0 & +4.0 & 5 & 11.5 & 11.5 & 0.0 \\
\hline 6 & 9.0 & 9.0 & 0.0 & 6 & 9.0 & 9.0 & 0.0 \\
\hline 7 & 8.0 & 11.0 & +3.0 & 7 & 8.0 & 9.0 & +1.0 \\
\hline 8 & 6.0 & 10.0 & +4.0 & 8 & 9.5 & 11.0 & +1.5 \\
\hline 9 & 8.0 & 9.0 & +1.0 & 9 & 2.0 & 10.0 & +8.0 \\
\hline Mean & 7.22 & 9.72 & +2.50 & Mean & 8.17 & 9.83 & +1.67 \\
\hline
\end{tabular}

Table-2. Paired sample t-test of the difference between the mean scores for writing performance before and after the intervention for the control group.

\begin{tabular}{|c|c|c|c|c|c|c|c|c|}
\hline \multirow{3}{*}{ Control group } & \multicolumn{5}{|c|}{ Paired Differences } & \multirow[t]{3}{*}{$\bar{t}$} & \multirow[t]{3}{*}{ df } & \multirow{3}{*}{$\begin{array}{l}\text { Sig (2- } \\
\text { tailed) }\end{array}$} \\
\hline & \multirow[t]{2}{*}{$\begin{array}{c}\text { Mean } \\
\text { Diff }\end{array}$} & \multirow[t]{2}{*}{ S.D. } & \multirow{2}{*}{$\begin{array}{c}\text { Std. } \\
\text { Error } \\
\text { Mean }\end{array}$} & \multicolumn{2}{|c|}{$\begin{array}{c}95 \% \text { confidence internal } \\
\text { of the difference }\end{array}$} & & & \\
\hline & & & & lower & upper & & & \\
\hline Pre-test-Post-test & 1.67 & 1.56 & 0.52 & 0.46 & 2.87 & 3.20 & 8 & $0.013^{*}$ \\
\hline
\end{tabular}
Note: ${ }^{*} \mathrm{p}<.05$

Table-3. Wilcoxon matched-pairs signed rank test of the difference between the mean scores for writing performance before and after the intervention for the experimental group.

\begin{tabular}{c|c}
\hline Experimental group & Pre-test Rank - Post-test Rank \\
\hline W & -2.53 \\
\hline Sig (2-tailed) & $0.012^{*}$ \\
\hline
\end{tabular}

The result of the paired sample t-test revealed that there was a significant mean score difference between the pre-test and post-test writing performance for the control group, $[\mathrm{t}(8)=3.20, \mathrm{p}<.05]$. On the other hand, the Wilcoxon matched pairs signed rank test indicated that the post-test ranks were statistically significantly higher than the pre-test ranks for the experimental group, $\mathrm{W}(8)=-2.53, \mathrm{p}<.05$. Therefore, it can be concluded that there is a significant difference in the mean scores for writing performance before and after Peer-Modo feedback for both the experimental group and the control group. The value of Cohen's $d$ was 0.44 for the experimental group and 0.56 for the control group, which suggested a medium effect with a moderate difference in pupils' writing performance scores before and after using Peer-Modo feedback. Furthermore, this implied that Peer-Modo feedback was a predictor of pupils' improvement in English writing. The result is in line with Huang (1999), Sharadgah (2013), and Sacktein (2017), who all found that proper instructional strategies help learners to garner ideas before proceeding to the drafting stage. Through instructional strategies such as free writing in pairs, the respondents were able to discuss the writing task together while exchanging ideas. Similar to the findings of Yusof et al. (2012), when pupils were exposed to new perspectives and provided with more practice in language development and writing ability before proceeding to the drafting stage, there was a positive effect on pupils' writing performance. The pre-test and post-test results were also congruent with the findings of Kuyyogsuy (2019) who reported statistically significant differences between pupils' mean scores for writing pre-test and post-test in examining the impacts of peer feedback on students' English writing skills. Additionally, this corresponded to the findings of Kusumaningrum, Cahyono, and Prayogo (2019) who reported that pupils could enhance their written tasks by correcting peers' work. They showed that pupils could develop efficacy in writing through peer feedback. However, as shown in Table 1, the experimental group, in which respondents acted as both feedback receivers and reviewers showed greater improvement than the control group in which respondents only acted as reviewers. This result is contrary to the findings of Lundstrom and Baker (2009). Nevertheless, the improvements made by the control group imply that, although they did not receive feedback for their writing outlines, their participation in giving feedback improved their writing skills.

\subsection{Is there any Significant Improvement in Terms of Content Quality of Year 4 Pupils' Writing Product?}

Another paired sample t-test and a document analysis were conducted to scrutinize pupils' writing performances on the basis of the content of the respondents' writing product. Content quality was one of the major writing features in the pre-test and post-test scoring of writing. This writing feature has a significant place in the marking rubric Figure 1 and was therefore used by the three markers to score each piece of writing. Besides that, content quality was also highlighted in the Peer-Modo feedback task posted on Edmodo, as shown in Figure 2. To know whether there was any significant difference in the mean scores for each writing feature within each group, the pre-test and post-test content quality were compared, as shown in Table 4.

Table-4. Paired sample T-tests of the difference between the mean score for content quality on pre-test and post-test of experimental and control groups.

\begin{tabular}{|c|c|c|c|c|c|c|c|}
\hline & $\begin{array}{l}\text { Writing } \\
\text { features }\end{array}$ & $\begin{array}{c}\text { Writing } \\
\text { Test } \\
\end{array}$ & $\begin{array}{l}\text { Mean } \\
\text { score } \\
\end{array}$ & Mean Diff & $\mathbf{t}$ & df & Sig (2-tailed) \\
\hline \multirow{2}{*}{ Experimental group } & \multirow{2}{*}{ Content } & Pre & 1.89 & \multirow{2}{*}{+1.11} & \multirow{2}{*}{2.79} & \multirow{2}{*}{8} & \multirow{2}{*}{$0.023^{*}$} \\
\hline & & Post & 3.00 & & & & \\
\hline \multirow{2}{*}{ Control group } & \multirow{2}{*}{ Content } & Pre & 2.17 & \multirow{2}{*}{+0.89} & \multirow{2}{*}{3.25} & \multirow{2}{*}{8} & \multirow{2}{*}{$0.012^{*}$} \\
\hline & & Post & 3.06 & & & & \\
\hline
\end{tabular}

Note: ${ }^{*} \mathrm{p}<.05$ 
Judging their essay in accordance with the rubric, the mean pre-test scores indicated that most of the pupils' writing only had relevant main ideas without supporting details. The post-test score results of both groups implied that their writing had been refined from one main idea with a relevant supporting detail to at least two main ideas with two relevant supporting details. As Table 4 shows, there was a statistically significant difference in both the experimental group $[\mathrm{t}(8)=3.09, \mathrm{p}<.05]$ and the control group $[\mathrm{w}(9)=3.25, \mathrm{p}<.05]$ with regards to the level of content quality. This indicates that Peer-Modo feedback had a strong effect on the content quality of respondents' essays. The respondents developed more insights as they engaged in giving and receiving feedback during the feedback intervention. In fact, for the purpose of the Peer-Modo feedback activity, one task regarding the content level of each essay was explicitly given with these instructions: 'Task 1: If you find the introduction, body and/or conclusion DO NOT HAVE a match, make suggestions by giving examples of your own. Check whether they are clearly written and easy to understand.' Some samples of free writing products from the experimental group and the corresponding Peer-Modo feedback are shown in Figure 3 and Figure 4.

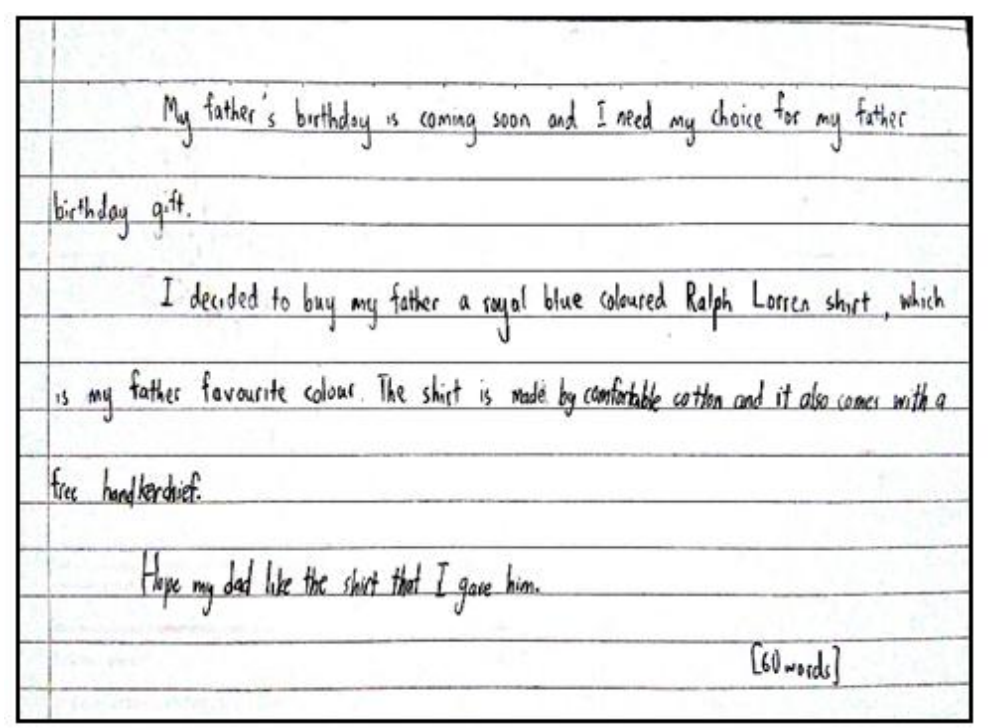

\begin{tabular}{|c|c|c|c|}
\hline \multirow{2}{*}{ 8. } & \multicolumn{3}{|l|}{ Teh Yuan Xing } \\
\hline & \multicolumn{3}{|c|}{$\begin{array}{l}\text { You can add some supporting detalls like "My father likes } \\
\text { blue colour." }\end{array}$} \\
\hline & \multicolumn{3}{|l|}{ Translate } \\
\hline & \multirow{2}{*}{\multicolumn{2}{|c|}{2 Likes $\cdot$ Reply $\cdot$ Sep $=$}} & Give suggestions \\
\hline \multirow{2}{*}{9} & & & Yap Yu \\
\hline & \multicolumn{3}{|c|}{$\begin{array}{l}\text { Task 1: there are two missing supporting detail at the } \\
\text { second point and third point }\end{array}$} \\
\hline & \multicolumn{3}{|l|}{ Translate } \\
\hline \multicolumn{4}{|c|}{ Identifying lacking of supporting details } \\
\hline \multirow[t]{4}{*}{$\odot$} & \multicolumn{3}{|l|}{ Wong $X_{v}$} \\
\hline & \multicolumn{3}{|c|}{$\begin{array}{l}\text { Task } 2 \text { : i realised i did not add enough supporting details } \\
\text { too. }\end{array}$} \\
\hline & \multicolumn{3}{|l|}{ Translate } \\
\hline & 3 Likes - Rep! & Activ & ate awareness \\
\hline
\end{tabular}

Figure-3. Free writing products of experimental group Pair 1 and Peer-Modo feedback received.

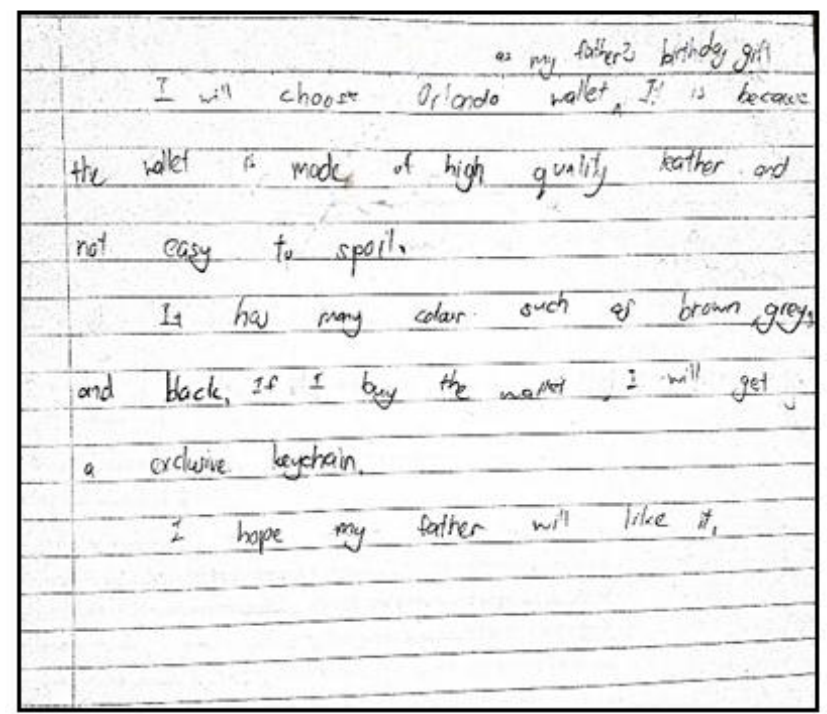

Boo Zhuang

Task 1

\begin{tabular}{|l|l|}
\hline The second main idea no supporting details & $\begin{array}{l}\text { Identifying lacking } \\
\text { of supporting details }\end{array}$ \\
\hline Translate &
\end{tabular}

1 Like $\cdot 3$ Replies $\cdot$ Oct 01, 2019, 11:11 AM

Boo Zhuang

I suggest the second main idea supporting detalls can write about

his father favourite colour.

Such as, My father favourite colour is black colour.

1 Like - Oct 01, 2019, 11:15 AM

C Craeven Tiew Whey Ee

I suggest to change the word "not easy to spoil " to "it is durable 1 Like - Oct 01, 2019, 11:17 AM

(3)
Give suggestions

...leather which makes it more ciurable.

Like - Oct 02, 2019, 12:11 AM

Figure-4. Free writing products of experimental group Pair 8 and Peer-Modo feedback received.

The analysis of the Peer-Modo feedback on other respondents' free writing revealed that respondents actively engaged in identifying the lack of supporting details, thereby creating self-awareness in evaluating their own and others' essays, and giving suggestions to help others improvise ideas. Respondents then had to decide whether they agreed to adopt the ideas they had been given or whether to alter them to make them their own. Figure 5 and Figure 6 show the comparison and analysis of an outstanding improvement of writing performance in terms of content from both groups.

According to the marking rubric, a main idea is followed by a supporting detail. As the pupils engaged in PeerModo feedback, they logically generated more ideas, providing a supporting detail that was closely related to each main idea. The development of the writing was more than adequate. By adding supporting details after each main idea, they produced a longer text. Peers can introduce pupils to new ideas, resulting in peer feedback that exposes pupils to an array of alternative ideas that can make a positive impact on their writing (Huisman, Saab, Van Driel, \& Van Den Broek, 2018). 


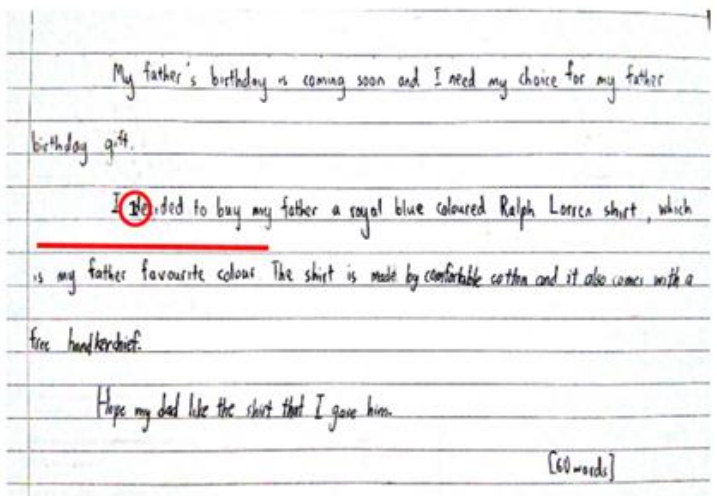

* Lack of supporting details as there is only 1 supporting detail. Anyway, the ideas are relevant.

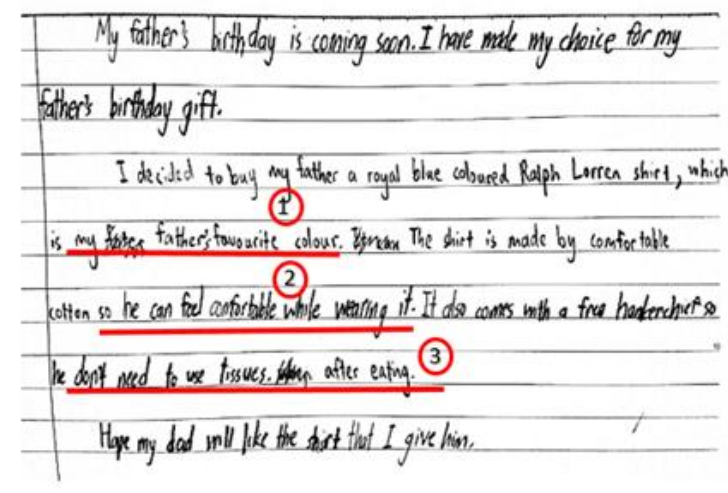

*All the main points were well-supported with relevant ideas.

\section{(1) The first main points was enhanced with relevant supporting detail. \\ (2) The second main points were enhanced with relevant supporting detail. \\ (3) The third main points were enhanced with relevant supporting detail.}

Figure-5. Comparison and analysis in terms of content of pre-test and post-test writing of experimental group Pair 1.

Pre-test writing

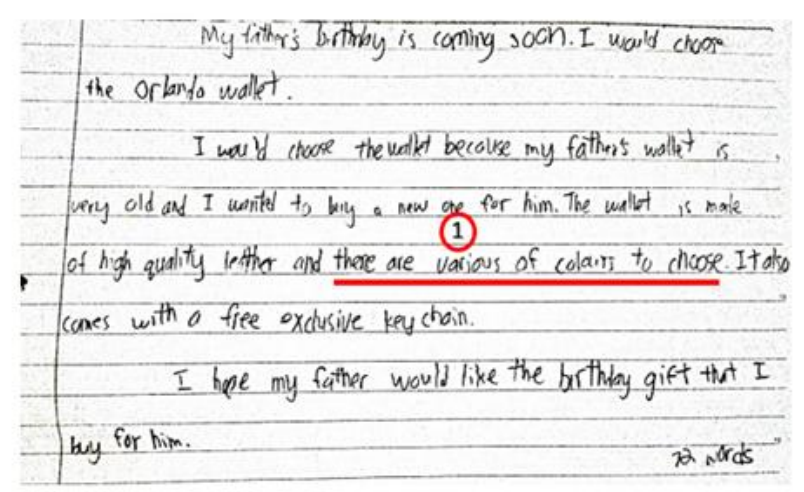

* Ideas are relevant. There is only 1 supporting detail. Lack of supporting details.

(1) Supporting detail for the second main idea.

(2) Supporting detail for the first $/$ main idea.

(3) Supporting detail for the third main idea.

Figure-6. Comparison and analysis in terms of content of pre-test and post-test writing of control group Pair 4.
Post-test writing

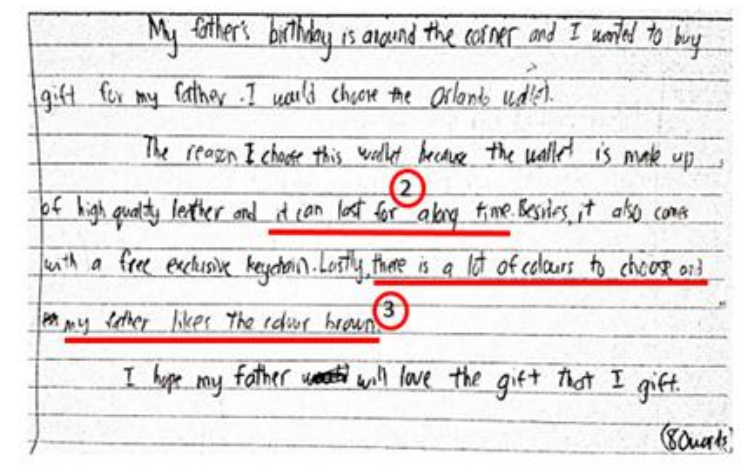

* Enhanced with two relevant supporting details.

Likewise, using peer feedback at the pre-writing stage yielded the same result as in the revision of students' written tasks, which was to increase the content quality of their writing. Figure 6 shows that although the prewriting products of respondents from the control group were not reviewed by their peers, their engagement in Peer-Modo feedback also caused them to generate more ideas. It was believed that more insights would be obtained by the feedback givers in the control group as they were involved in direct interactions with their peers during the peer-feedback giving session. Therefore, engagement in Peer-Modo feedback could improve the content quality of their writing as the Edmodo platform helped them to appreciate the peer feedback and others' writing throughout the entire writing process. Additionally, Calimbo et al. (2016) pointed out that content is a higher order concern in essay writing. Peer-Modo feedback can help to produce pupils that have the ability to analyse their own and others' writing, anticipate and respond to criticism critically and logically, and ultimately make the decision to select, set aside or develop new ideas based on the feedback they received. This notable result of the post-tests also confirms that Peer-Modo feedback can assist in building up respondents' thinking skills and help them to perform at a higher order thinking level, on par with one of the six key attributes of student aspirations advocated in the Malaysian Education Blueprint (2013-2025; E10).

\section{Conclusion and Recommendations}

As globalization and digitalization are increasingly influencing how pupils learn in education, the ESL classroom should deviate from conventional methods of teaching writing to incorporate new approaches that aim at integrating student-centred learning, interaction, technology, and lifelong skills. This empirical study has shown that Peer-Modo feedback at the pre-writing stage benefits pupils' writing performance in terms of content quality, as their writing proceeds from the drafting stage to the final draft stage. Even though some pupils only play the role of assessors without receiving feedback from others on their own writing, they still manage to improve their written content. Nevertheless, the present study is not free from limitations. The small number of respondents causes the conclusions to be restricted to broad generalisations, as only 36 Year 4 respondents were involved. In addition, the English proficiency of all pupils in the current study was at intermediate level. Pupils' level of acceptance and adaptation towards the strategy may differ from those of a lower English proficiency level. Therefore, there is a need for other studies to be conducted on a larger number of respondents over an extended period of time. Future research could also further explore ways to implement Peer-Modo feedback in other 
populations, catering to pupils with below-intermediate proficiency levels.

\section{References}

Abdullah, S. N. A., Hashim, H., \& Mahmud, M. S. (2018). Using mobile application as an alternative to pre-writing strategy. International Journal of Engineering \& Technology, 7 (4), 147-169.

Atikah, D. (2013). The effectiveness of teacher and peer feedback in teaching hortatory exposition writing. Journal of English Department.

Calimbo, A. C. B. S., Arambala, M. D. P., Sususco, A. B., \& Talle, O. P. P. (2016). Effects of collaborative evaluation techniques on students' writing performance. The English Teacher, 45(1), 21-30.

Chamot, A. U. (1999). Teaching learning strategies to language students. Washington DC: Center for International Education.

Fareed, M., Ashraf, A., \& Bilal, M. (2016). ESL learners' writing skills: Problems, factors and suggestions. Journal of Education and Social Sciences, 4(2), 81-92.

Geyimci, G. (2014). Prewriting techniques in the writing process for the L2 classroom. International Journal of English Language E Translation Studies, 2(3), 77-84.

Go, A. S. (1994). Prewriting activities: Focus on the process of writing (No. ED369257). Educational Resources Information Centre. Retrieved from: https://files.eric.ed.gov/fulltext/ED369257.pdf.

Grenfell, M., \& Harris, V. (1999). Modern languages and learning strategies: In theory and practice. London: Routledge.

Huang, S. (1999). EFL students' use of ideas provided by peers during prewriting discussions conducted on networked computers (No. ED428563). Educational Resources Information Centre. Retrieved from: https://files.eric.ed.gov/fulltext/ED428563.pdf.

Huisman, B., Saab, N., Van Driel, J., \& Van Den Broek, P. (2018). Peer feedback on academic writing: undergraduate students' peer feedback role, peer feedback perceptions and essay performance. Assessment $\mathcal{E}^{2}$ Evaluation in Higher Education, 43(6), 955-968.

Kusumaningrum, S. R., Cahyono, B. Y., \& Prayogo, J. A. (2019). The effect of different types of peer feedback provision on efl students' writing performance. International Journal of Instruction, 12(1), 213-224.

Kuyyogsuy, S. (2019). Promoting peer feedback in developing students' english writing ability in L2 writing class. International Education Studies, 12(9), 76-90.

Latifi, S., Noroozi, O., Hatami, J., \& Biemans, H. J. (2019). How does online peer feedback improve argumentative essay writing and learning? Innovations in Education and Teaching International, 1-12.Available at: https://doi.org/10.1080/14703297.2019.1687005.

Lim, I. K., Yunus, M. M., \& Embi, M. A. (2017). Build me up: Overcoming writing problems among pupils in a rural primary school in Belaga, Sarawak, Malaysia. Jurnal Pendidikan Humaniora, 5(1), 1-7.Available at: https://doi.org/10.17977/um030v5i12017po01.

Lo, J., \& Hyland, F. (2007). Enhancing students' engagement and motivation in writing: The case of primary students in Hong Kong. Journal of Second Language Writing, 16(4), 219-237.Available at: https://doi.org/10.1016/j.jslw.2007.06.002

Lundstrom, K., \& Baker, W. (2009). To give is better than to receive: The benefits of peer review to the reviewer's own writing. Journal of Second Language Writing, $18(1)$, 30-43.Available at: https://doi.org/10.1016/j.jslw.2008.06.002.

Mendonca, C. O., \& Johnson, K. E. (1994). Peer review negotiations: Revision activities in ESL writing instruction. TESOL Quarterly, 28(4), 745-769.Available at: https://doi.org/10.2307/3587558.

Ministry of Education Malaysia. (2015). The english language curriculum for primary schools. Putrajaya, Malaysia: Kementerian Pendidikan Malaysia.

Mogahed, M. M. (2013). Planning out pre-writing activities. International Journal of English and Literature, 4(3), 60-68.

Mohamad, M., Ghazali, N., \& Hashim, H. (2018). Secondary school students' perceptions on the use of Google+ towards improving ESL writing skills. International Journal of Emerging Technologies in Learning (iJET), 13(09), 224-238.Available at: https://doi.org/10.3991/ijet.v13io9.8479.

Moussaoui, S. (2012). An investigation of the effects of peer evaluation in enhancing Algerian student's writing autonomy and positive affect. Procedia-Social and Behavioral Sciences, 69, 1775-1784.Available at: https://doi.org/10.1016/j.sbspro.2012.12.127.

Parthasarathy, R. (2014). Peer feedback in the esl writing classroom. A Journal of Teaching English Language and Literature, 29(July 2014), 2629.

Sacktein, S. (2017). Peer feedback in the classroom empowering students to be the experts. USA: ASCD.

Said, N. E. M., Yunus, M., Doring, L. K., Asmi, A., Aqilah, F., \& Li, L. K. S. (2013). Blogging to enhance writing skills: A survey of students' perception and attitude. Asian Social Science, 9(16), 95-101.Available at: https://doi.org/10.5539/ass.v9n 16p95.

Sharadgah, T. A. (2013). Writing in an Internet-based environment: Improving EFL students' writing performance through text-based chat. International Journal of Humanities and Social Science, 3(14), 258-266.

Tompkins, G. (2001). Literacy for the 21st Century: A balanced approach. Columbus, OH: Merrill Prentice Hall.

Tusino. (2013). The effectiveness of peer editing to improve the students' essay writing skill. Jurnal Penelitian Humaniora, 14(2), 133-143.

Yang, Y. F., \& Meng, W. T. (2013). The effect of online feedback training on students' text revision. Language Learning \& Technology, 17(2), $220-238$.

Yunus, M. M., Hashim, H., Sulaiman, N. A., Sulaiman, W. S. M., Richmond, R. L., Jarail, S., \& Royal, N. (2018). Students' Awareness and Perceptions towards "Pre-Writing Stage" as a Strategy in Writing Directed Essay. Creative Education, 9(14), 2215 -2223.

Yusof, J., Ab Manan, N. A., \& Alias, A. A. (2012). Guided peer feedback on academic writing tasks using facebook notes: An exploratory study. Procedia-Social and Behavioral Sciences, 67, 216-228.Available at: https://doi.org/10.1016/j.sbspro.2012.1 1.324. 